\title{
Nutraceutical and Antioxidant Properties of the Seeds, Leaves and Fruits of Carica papaya: Potential Relevance to Humans Diet, the Food Industry and the Pharmaceutical Industry - A Review
}

\author{
Oseni Kadiri $^{1 *}$, Babatunde Olawoye ${ }^{1}$, Olumide S. Fawale ${ }^{2}$, Olusoji Adeola Adalumo ${ }^{3}$ \\ ${ }^{1}$ Department of Food Science and Technology, Obafemi Awolowo University, PMB 13, Ile-Ife, Nigeria \\ ${ }^{2}$ Nigerian Institute for Oceanography and Marine Research \\ ${ }^{3}$ Department of Physiology, Federal University of Technology Akure, P.M.B. 704, Nigeria
}

\section{A R T I C L E I N F O}

Article history:

Received 29 October 2015

Accepted 21 July 2016

Available online, ISSN: $2148-127 \mathrm{X}$

Keywords:

Carica papaya

Nutraceutical

Antioxidant

Medicinal

Pharmacological

Corresponding Author:

E-mail: kadirioseni@yahoo.com \begin{abstract}
A B S T R A C T
Pawpaw (Carica papaya Linn) seeds, peels and leaves are well known for their medicinal and potent pharmacological values. The plant belongs to the family Caricaceae and its fruit is commonly known for its food and nutritional values. Though the roots, bark, peel, pulp and the seeds had been shown to have medicinal properties, little is known about their nutritional properties. During the last few years, there had been series of research to explore further pharmacological and medicinal properties as well as it nutritional qualities of these plants parts, thus giving rise to it nutraceutical abilities. Scientific attempts have also been made over the decades to authenticate its nutraceutical properties. While nutritional constituents such as oil, proteins, and minerals haven been characterised from its seeds, little is known about other parts of the plant. Though the nutraceutical properties of papaya as drug or quasi-food product are not well understood or value, still it is an important gift of nature that is readily available in our eco-world and worth exploring. This review focuses on previous studies by various researchers on the medicinal, nutraceutical properties as well as the antioxidant potential of these plant parts and suggestions for further studies as regarding the optimisation of the potential of this plant.
\end{abstract}

\section{Introduction}

Pawpaw (Carica papaya Linn) is the most important fruit in the Caricaceae family with over 22 species (Fig. 1). Only one member of the genus Carica is cultivated as the fruit tree (Claudia et al., 2014). According to Food and Agriculture Organization (FAO, 2007), it is an invaluable plant that is prevalent throughout tropical Africa and Nigeria is the third largest producer globally. The many benefits of papaya are owed due to the high content of vitamin A, B and C, proteolytic enzymes like papain and chymopapain which have antiviral, antifungal and antibacterial properties (Tarum and Yash, 2015) .Pawpaw fruit contains papain which is a major component of papaya latex. Papain is widely applied for meat tenderisation according to a report of Feng (2014). Green Pawpaw fruit had been reported by Duke (1996) to provide (per $100 \mathrm{~g}$ ) 26 calories, $92.1 \mathrm{~g} \mathrm{H} 2 \mathrm{O}, 1.0 \mathrm{~g}$ protein, $0.1 \mathrm{~g}$ fat, $6.2 \mathrm{~g}$ total carbohydrate, $0.9 \mathrm{~g}$ fibre and $0.6 \mathrm{~g}$ ash. USDA National Nutrient database reported an oval fresh ripe papaya (per $100 \mathrm{~g}$ ) (Fig. 2) to contain 39 calories, $88.8 \mathrm{~g} \mathrm{H} 2 \mathrm{O}, 0.61 \mathrm{~g}$ protein, $0.14 \mathrm{~g}$ fat, $9.81 \mathrm{~g}$ total carbohydrate, $1.8 \mathrm{~g}$ fibre and $0.61 \mathrm{~g}$ ash . A similar finding was likewise reported by Krishna et al. (2008) (Table1) on the nutritional constituents of the fruit. Oyoyede (2005) likewise reported the chemical profile of unripe pulp of pawpaw to be rich in carbohydrate
(42.28\% starch, $15.15 \%$ sugar) but low in fat content. Papaya fruit contains high levels of vitamin C (51.2 $\mathrm{mg} / 100 \mathrm{~g})$, vitamin A precursors including $\beta$-carotene $(232.3 \mu \mathrm{g} / 100 \mathrm{~g})$, and $\beta$-cryptoxanthin $(594.3 \mu \mathrm{g} / 100 \mathrm{~g})$, as well as magnesium (19.2-32.7 mg/100g) (Wall, 2006). Furthermore, Oyoyede (2005) and Bari et al. (2006) also reported pawpaw fruit to be rich in carbohydrates (42.28\% starch and $15.15 \%$ sugar in pulp), but deficient in protein and fat. About per $100 \mathrm{~g}$ of the fruit provides 39 kcal $(163 \mathrm{~kJ})$ energy and it is a very important food source in some developing countries (Feng, 2014). Pawpaw leaves have been reported to be in used in some developing countries for cooking (Feng, 2014) and the fresh leaves processed into tea leaf by Dev and Igab (2015). Duke (1996) reported the leaves to be high in protein (7.0 g), calcium (334 mg), phosphorus (142 mg), sodium $(16 \mathrm{mg})$, vitamin $\mathrm{B}$ and vitamin $\mathrm{E}(136 \mathrm{mg})$. In recent years, papaya latex and its commercial products have become acceptance in use in baking, beverage industries, pharmacy and chemicals synthesis (Feng, 2014).

Besides its nutritional properties, Carica papaya plant has to find usefulness as an important medical plant due to its specific enzymes and bioactive compounds. Carica papaya seed extracts had been shown to have several 
medicinal as well as nutritional properties (Mello et al., 2008). The seeds and leaves consist of the significant amount of protein which could be harness for food formulation or supplementation. Extraction and commercialization of oil from Carica papaya is an established process in the manufacturing sector. Papain found in both papaya fruits and latex had been utilised for medical benefits in Central America for decades (Feng, 2014). Papain and other endopeptidases have been proven to have several medical benefits, such as defibrinating wounds and treatment of oedemas (Nitsawang et al., 2006). An earlier study by Starley et al. (1999) reported that some specific antimicrobial substrates including carpaine and aglycones are present in pawpaw, which could be beneficial to health. Oyoyede (2005) also reported that the extract of papaya fruits and seeds has antibacterial activity against Staphylococcus aureus, Bacillus cereus, Esherischia coli, Pseudomanas aeruginosa and Shigella flexneri. Furthermore, Carica papaya fruits had been used in several other applications, such as the relief of nervous pains and elephantoid growth (Feng, 2014).

This review report research finding on the nutritional, antioxidants as well as the pharmacological and medicinal values of this plant with emphasis on the seed and leaf as well as the possibilities of having all these properties in a single food or drug supplements which can be coin into the term 'Nutraceutical'

\section{Methods Used For Literature Collection}

Literature survey was done in PubMed and Google's using keywords, Carica papaya; nutritional properties of Carica papaya; antioxidants in Carica papaya; nutraceuticals of Carica papaya; medical and pharmacological potentials of Carica papaya. Articles indexed in Google search, Google scholar, Science Direct, Wiley and PubMed journals were primarily considered for writing this review.

\section{Papaya Plant}

Carica papaya is a member of the Caricaceae (Table 2). It is a dicotyledonous, polygamous and diploid species that is known for its ability to fruit throughout the year. The plant is recognised by its weak and usually,

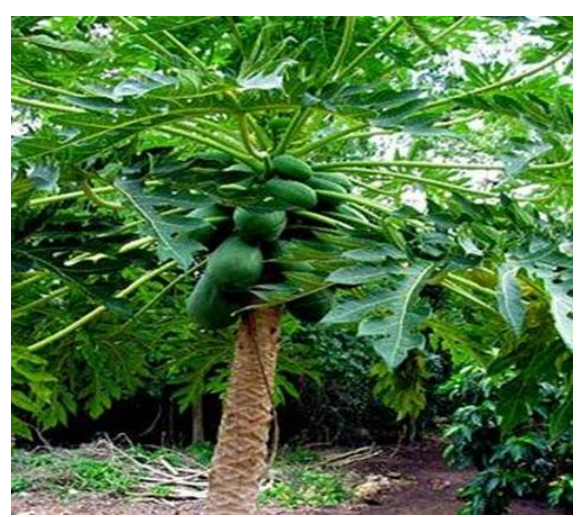

Figure1 Papaya tree with branches (Kadiri, 2015) unbranched soft stem yielding copious white latex and crowded by a terminal cluster of large and long-stalked leaves is rapidly growing and can grow up to $20 \mathrm{~m}$ tall (Banerjee and Banerjee,1989; Owoyele et al., 2008). Ripe Carica papaya fruit is usually consumed fresh as a dessert fruit or use in a juice blend. The peels of the fruit are used as livestock feed. The fruits, juice, seed, root, leaves, bark, latex of this plant consists of chemical compounds that are beneficial nutritionally as well as pharmaceutically (Table 3).

Papain, an important bioactive substance can be found in virtually every part of the plant. It has found a useful application in tenderising meat (Ahmad et al., 2011; Feng, 2014) and in beer clarification. The usefulness as food, medicinal and pharmacological potentials had made this plant an economic viable agricultural crop (Table 3). In recent times, attentions are been diverted from its medicinal and pharmaceutical qualities of the plant part to the application in nutrition.

Papaya seeds are found embedded in the fruit. They are whitish in colouration in the immature stage of the fruit development and darkish in colour when at full maturation of the fruit. It is spherical in shape with an outer coating known as the sarcotesta covering the seed coat and an inner endosperm (Figure 3). The seed pericarp is rich in protein (Adesuyi and Ipinmoroti, 2011) while the endosperm is rich in oil and protein (Syed et al., 2012). Papaya seeds are a rich source of amino acids especially in the sarcotesta (Saran and Ravish, 2013).

The domestic and industrial utilisation of Carica papaya fruit creates major disposal problems in the form of the seed which constitutes $25 \%$ of the fruit mass. Disposal of these seeds materials is often compounded by legal restrictions and economy cost to the industry. The peel and pulp are the other categories of waste from the industrial and domestic utilisation of the fruit. This "waste material" produces ecological problems related to the proliferation of insects and rodents and an economic burden because of transportation to repositories; therefore strategies for the profitable use of these materials are needed (Hussein et al., 2011). Making these seeds, leaves or peels economic viable will reduce the economic burden pose to industries making use of the fruit for juice production hence the needs for research scholars to place more emphasis on how the potential of these plant can be optimise.

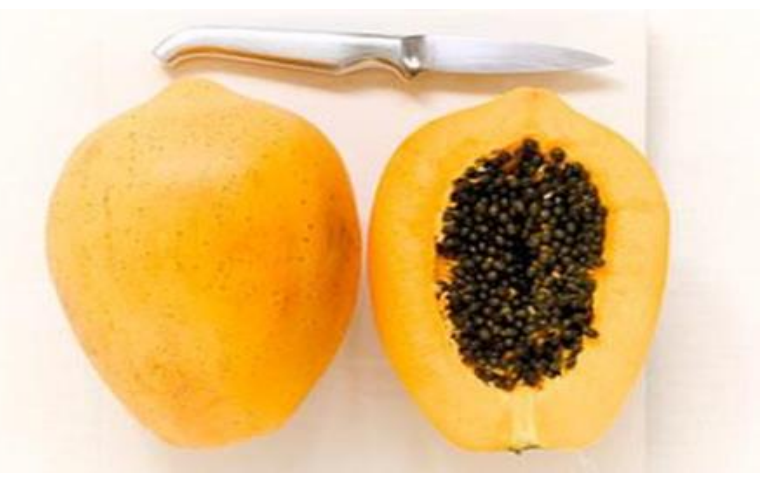

Figure 2 Pawpaw Fruit with the Seeds, (Kadiri, 2015) 
Table 1 Nutritional composition of ripe and unripe pawpaw fruits (Source: Krishna et al. 2008)

\begin{tabular}{l|cc}
\multicolumn{1}{c|}{ Chemical composition } & Ripe pawpaw fruit & Unripe pawpaw fruit \\
\hline Protein & $0.6 \mathrm{~g}$ & $0.7 \mathrm{~g}$ \\
Fat & $0.1 \mathrm{~g}$ & $0.2 \mathrm{~g}$ \\
Crude fibre & $0.8 \mathrm{~g}$ & $0.9 \mathrm{~g}$ \\
Carbohydrate & $7.2 \mathrm{~g}$ & $5.7 \mathrm{~g}$ \\
Energy & $32 \mathrm{kcal}$ & $27 \mathrm{kcal}$ \\
Total carotene & $2,740 \mu \mathrm{m}$ & 0 \\
Beta carotene & $888 \mu \mathrm{m}$ & 0 \\
Minerals & $0.5 \mathrm{~g}$ & $0.5 \mathrm{~g}$ \\
\hline
\end{tabular}

Table 2 Botanical classification of Carica papaya

\begin{tabular}{l|l}
\hline \multicolumn{1}{c|}{ Domain } & \multicolumn{1}{c}{ Flowering plant } \\
\hline Kingdom & Plantae \\
Sub-Kingdom & Trancheobionta \\
Class & Magnoliopsida \\
Subclass & Dilleniidae \\
Super division & Spermatophyta \\
Phylum & Steptophyta \\
Order & Brassicales \\
Family & Caricaceae \\
Genus & Carica \\
Botanical Name & Carica papaya Linn \\
\hline
\end{tabular}

Table 3 Nutraceutical potentials of the Carica papaya plant*

\begin{tabular}{l|l}
\hline \multicolumn{1}{c|}{ Part } & \multicolumn{1}{c}{ Constituents } \\
\hline Fruits & $\begin{array}{l}\text { Protein, fat, fibre, carbohydrates, mineral: calcium, phosphorous, iron, vitamin C, thiamine, } \\
\text { riboflavin, niacin and carotene, amino acids, citric and malic acids (green fruit) } \\
\text { N-butyric acids, n-hexanoic and n-octanoic acids, lipids, Myristic, planets, stars, linoleic, linolenic } \\
\text { and cis-vaccenic and oleic acid }\end{array}$ \\
Suice & $\begin{array}{l}\text { Fatty acids, crude protein, crude fibre, papaya oil, Potassium, Calcium, Magnesium, carpaine, } \\
\text { benzylisothiocynate, benzylglucosinolate, glucotropacolin, benzylthiourea, hentriacontane, } \beta-\end{array}$ \\
& $\begin{array}{l}\text { sitostrol, caressing and enzyme myrosin } \\
\text { Carposide and enzyme myrosin }\end{array}$ \\
Root & $\begin{array}{l}\text { Alkaloids carpain, pseudocarpain and dehyrocarpaine and ,choline, carposide vitamin C and E } \\
\text { Leaves }\end{array}$ \\
Bark & $\begin{array}{l}\text { Proteolytic enzymes, papain and chemopapain, glutamine, cyclotransferase, chymopapains A, B } \\
\text { and C, peptidase A and B and lysozymes. }\end{array}$ \\
\hline *(Source: Rehman et al. 2003; Krishna et al. 2008; Kadiri, 2015)
\end{tabular}

*(Source: Rehman et al. 2003; Krishna et al. 2008; Kadiri, 2015)

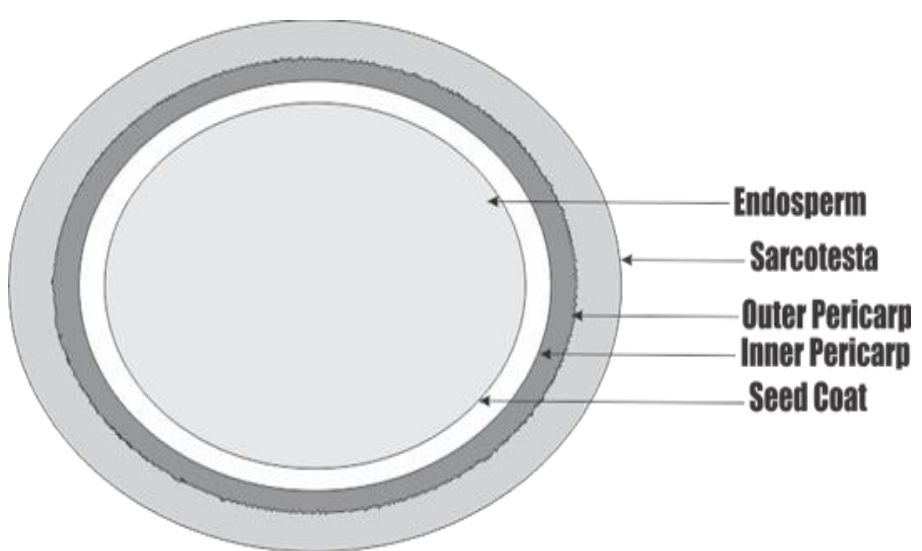

Figure 3 Structure of the Carica papaya seed 


\section{Nutritional Composition of Carica Papaya Seed Flour}

Flours produced from Carica papaya seeds are rich in nutritional constituents such as amino acid, protein, oil, crude fibre and mineral elements (Claudia et al., 2014; Adesuyi and Ipinmoroti, 2011; Samia et al., 2012; Cassia et al., 2011; Kadiri,2015) (Table 4). The oil composition of a $100 \mathrm{~g}$ papaya seed flour ranges between $29-32 \mathrm{~g}$ whole seed weight (Table 4). In a study by Cassia et al. (2010), high-quality oleic oils were extracted from the seeds. Even though the potential utilisation of the seeds for oil seems favourable, it was suggested that toxicological studies need to be carried out before the oil can be said to be appropriate for food applications. Crude fibre and ash content are relatively low in Carica papaya seed but the major area that has generated quite some interest is the oil and protein content which are relatively high in composition, though the antioxidant properties is now a recent area of interest.

\section{Protein value of Carica Papaya}

Papaya seed has a considerable amount of protein content (Table 4). Protein composition of $28.55 \%$ was estimated in flour produced from the seeds (Claudia et al., 2014). The protein content of some commonly consumed oil seed in Nigeria namely Coloccynthis citrullus, peanut flour, rapeseed and sunflower $(28.44,24.3,25$ and $28.7 \%$ respectively) had been reported to be relatively lower to that of papaya seed flour (Jackson, 2000). This makes it a likely ingredient and additives in foods such as meat products, doughnuts pancakes and in the stabilisation of colloidal food systems where water and oil binding properties are of prime importance (Samia et al., 2012).

\section{Oil Value Carica Papaya}

Documented studies on the fat and oil content of the papaya seeds reveal significant fat and oil content (Table 4). Shadi et al. (2013) stated that the oil contents from papaya seed (30-34\%) compares favourably well with oil obtained from olive fruit (22-24\%), grape seed (8-15\%), orange seed (32-35\%), apple seed(21-24\%), watermelon seed (50\%) and pumpkin seed (42-45\%). Physicochemical properties of the oil reveal an iodine value, saponification value, un-saponifiable value to $65.5 \%, 155.5 \%$, and $1.37 \%$, respectively. Oleic acid $(72.5 \%)$ is the major fatty acid of papaya seed. This is followed by palmitic acid (13.5\%) and stearic acid $(4.5 \%)$. It was also reported that papaya oil is good source of monounsaturated fatty acid and saturated fatty acids (Shadi et al., 2013). Ultrasound-assisted extraction was propose as an appropriate technique for recovering the oil from the seeds of the papaya seed as it produces seed oil with desirable fatty acid profile in relatively short extraction times and moderate conditions as compared to different solvent extraction methods. A report by Cassia et al. (2011) documented the physicochemical characteristics, fatty acid, tocopherol, and carotenoid composition of crude oil extracted from papaya (Carica papaya L.) seeds, Formosa variety. The oil yield from the seed was put at $29.16 \%$ which was comparable to the yield of other compared edible oils. The extracted oil had high oxidation resistance ( 77.97 hours) and has major fatty such as oleic $(71.30 \%)$, palmitic $(16.16 \%)$, linoleic $(6.06 \%)$, and stearic $(4.73 \%)$ acid. $\alpha$ and $\delta$-tocopherol were the predominant tocopherols with 51.85 and 18.89 mg.kg-1, respectively. The $\beta$-cryptoxanthin (4.29 mg.kg1) and $\beta$-carotene (2.76 mg.kg-1) were the carotenoids quantified, and the content of total phenolic compounds was estimated at $957.60 \mathrm{mg} . \mathrm{kg}-1$. Chemical characteristic of extracted oil as reported by Kalou et al. (2011) from seeds of Carica papaya compared well with varieties described by Marfo et al. (1989). Carica papaya seed oils are liquid at room temperature with palmitic acid as the main saturated fatty acid, while linoleic acid is the major unsaturated fatty acid in all lipid classes (Kalou et al., 2011). The oil content of this seed makes it a potential source for the production of oil both for industrial and domestic utilisation.

\section{Nutritional Composition of Carica papaya Fresh and Processed Leaf}

Studies on proximate composition of papaya leave reveals significant amount nutritional factors such as ash, protein and crude fibre (Maisarah et al., 2014; Dev and Igbal, 2015). Maisarah et al. (2014) reported freezing dried leaves of Carica papaya to have an ash, crude protein, crude fibre and carbohydrate content of $11.4 \%$, $33.4 \%, 14.1 \%$ and $38.4 \%$, respectively. This result agrees with recent studies of Dev and Iqbal, (2015) on the proximate composition of fresh and dried papaya leaves (Table 5). The moderate value of ash content as reported by Dev and Igbal (2015) suggests that the leaf of papaya might contain essentials minerals. A significant amount of protein content makes this leaf suitable for the supplementation of the food product with a high carbohydrate to protein ration while the presence of fibre in appreciable quantity would find usefulness as an aid to the digestion process. The presence of significant amount of ash, protein and fibre contents render this leaf a potentially viable plant that might find usefulness in humans and livestock's diet.

\section{Minerals Content Carica papaya}

Studies on the minerals content of Carica papaya seed flour revealed the significant presence of mineral elements such as calcium, potassium, sodium and phosphorus (Adesuyi and Ipinmoroti, 2011; Samia et al., 2012; Kadiri, 2015). Minerals are important compounds needed for the maintenance of essential human body functions. Claudia et al. (2014) observe that the levels of $\mathrm{P}, \mathrm{Ca}, \mathrm{Mg}, \mathrm{S}, \mathrm{Zn}$, and Fe were higher in seed flour of Carica papaya when compared to those found in the peel of the same plant. One hundred gram intake of papaya (Havai) can supply the human body of $16 \%, 127 \%, 37 \%$, $88 \%, 135 \%, 59 \%, 81 \%$, and $72.5 \%$ of potassium, magnesium, iron, zinc, manganese, copper, phosphorus, 
and calcium, respectively, and the cultivar Calimosa will supply $42 \%, 134 \%, 36 \%, 91 \%, 196 \%, 92 \%$, and $78 \%$ (Claudia et al.,2014), which is a pointer to its nutritional relevance. This observation agrees with the report of Kalou et al., (2011) on the ash and minerals content of Carica papaya seeds who reported an ash content of $3.2 \%$ and minerals which include $\mathrm{K}, \mathrm{Na}, \mathrm{Ca}, \mathrm{P}$ and $\mathrm{Mg}$ (Table $6)$.

However, $\mathrm{Ca}$ and $\mathrm{P}$ occur in higher quantities compared to all other element tested for. A recent report by Kadiri (2015) on the whole and defatted flour of Carica papaya seed validates this seed as rich sources of $\mathrm{Ca}, \mathrm{K}$ and $\mathrm{Na}$. The mineral contents of papaya leaf as reported by Maisarh et al. (2014) also shows a significant amount of $\mathrm{Ca}, \mathrm{Mg}, \mathrm{K}$ and $\mathrm{P}$ (Table 7) which affirms these findings. Sodium and iron were also detected in minute quantities.
Detected minerals in the seed and leaf of Carica papaya are nutritionally important as inorganic mineral elements such as potassium and calcium plays important roles in the maintenance of biological functions in human, normal glucose-tolerance and in the release of insulin from beta cells of islets of Langerhans which helps to control the glucose level of the human body (Kadiri, 2015).

\section{Antioxidant Property and Free radical Scavenging Activity}

Antioxidants are substances that can prevent or retard the oxidation of easily oxidizable materials such as fat, the functions of which are generally based on their abilities to scavenge reactive free radicals in food (MacDonald et al., 2006; Kadiri and Olawoye, 2015).

Table 4 Proximate compositions of pawpaw (Carica papaya) seeds flour*

\begin{tabular}{l|cccccc}
\multicolumn{1}{c}{ Parameter $(\%)$} & $\mathrm{a}$ & $\mathrm{b}$ & $\mathrm{c}$ & $\mathrm{d}$ & $\mathrm{e}$ & $\mathrm{f}$ \\
\hline Moisture & 7.3 & 7.6 & $\mathrm{ND}$ & 6.43 & $\mathrm{ND}$ & 5.56 \\
Oil & 30.1 & 29.4 & 32.56 & 29.16 & 29.72 & 29.33 \\
Protein & 28.1 & 36.3 & 31.26 & 25.63 & 28.55 & 25.18 \\
Ash & 8.2 & 10.6 & 8.89 & 8.27 & 6.94 & 7.00 \\
Crude Fibre & 19.1 & 7.8 & 5.19 & $30.51^{*}$ & 8.78 & 5.53 \\
Carbohydrate & 25.6 & 8.4 & 22.15 & $30.51^{*}$ & 20.73 & 27.60 \\
\hline
\end{tabular}

*Source: ${ }^{a}$ Syed et al. (2012); ${ }^{\mathrm{b}}$ Adesuyi and Ipinmoroti (2011); ${ }^{\mathrm{c}}$ Samia et al. (2012); ${ }^{\mathrm{d}} \mathrm{Cassia}$ et al. (2011); ${ }^{\mathrm{e}} \mathrm{Claudia}$ et al. (2014); ${ }^{\mathrm{f}} \mathrm{Kadiri}(2015)$

Table 5 Proximate composition of fresh and dried papaya leaves (Source: Dev and Igbal, 2015)

\begin{tabular}{l|cccc}
\hline \multirow{2}{*}{ Parameters } & \multicolumn{2}{c}{ Fresh Leaves } & \multicolumn{2}{c}{ Dried Leaves } \\
\cline { 2 - 5 } & Wet Basis & Dry Basis & Wet Basis & Dry Basis \\
\hline Moisture (\%) & 81.5 & 439.7 & 4.7 & 4.9 \\
Protein (\%) & 5.1 & 27.5 & 26.2 & ND \\
Fat (\%) & 0.5 & 2.7 & 10.8 & ND \\
Ash (\%) & 2.1 & 11.3 & 55.7 & 11.3 \\
Carbohydrate (\%) & 10.8 & 58.3 & 35.5 & 58.4 \\
Vitamin C (mg/100g) & 235 & 12682 & 37.3 \\
\hline
\end{tabular}

Table 6 Mineral Elemental Composition of Carica papaya seed*

\begin{tabular}{l|c}
\hline \multicolumn{1}{c}{ Minerals Element } & Composition $(\mathrm{mg} / 100 \mathrm{~g})$ of seed \\
\hline Calcium, Ca & 1821.0 \\
Magnesium, Mg & 28.7 \\
Potassium, K & 32.89 \\
Sodium, Na & 12.59 \\
Phosphorous, P & 1156.0 \\
\hline
\end{tabular}

*(Source: Kalou et al.2011)

Table 7 Mineral content (mg/100 g) of freeze-dried samples of papaya leaf*

\begin{tabular}{l|c}
\hline Minerals & Quantity \\
\hline $\mathrm{Ca}$ & 811.1 \\
$\mathrm{Mg}$ & 564.9 \\
$\mathrm{P}$ & 3625.2 \\
$\mathrm{Fe}$ & 10.9 \\
$\mathrm{Na}$ & 24.4 \\
\hline
\end{tabular}


Antioxidant properties of Carica papaya seeds, fruits, leaves, peels and aerial parts have been documented from various studies. Recent reports refer to Carica papaya be rich in antioxidants. Wong and Kong (2014) reported C. papaya seed to be a promising source of food antioxidants. The seeds of papaya are rich in total phenolic and total flavonoids in the ethyl acetate and nbutanol fractions, a reason attributed to its antioxidant activities (Kaibing et al., 2011; Vijay and Sriram, 2010; Wong and Kong, 2014; Kadiri and Olawoye, 2016). Chloroform-methanol extract of C. papaya seeds exhibits better active antioxidant as well as highest phenolic content when compared to the antioxidant activity of Annona squamosal seeds (Vijay and Sriram, 2010). Kaibing et al., (2011) documented the antioxidant activity antioxidant activities of the ethanol, petroleum ether, ethyl acetate, n-butanol and water extract fractions of the seeds extract with promising results as regarding the antioxidants properties of the seeds. Ethyl acetate fraction was observed to show the strongest DPPH and hydroxyl free radical scavenging activities, and its activities were stronger than those of ascorbic acid and sodium benzoate, respectively. N-butanol fraction demonstrated the greatest ABTS+ radicals scavenging activity. The ethyl acetate fraction and the n-butanol fraction didn't only showed higher antioxidant activities than the petroleum ether fraction, water fraction and ethanol fraction but also showed higher superoxide anion and hydrogen peroxide radicals scavenging activities than those of the other extract fractions. The high amount of total phenolic and total flavonoids in the ethyl acetate and n-butanol fractions were attributed to their antioxidant activities. The ethyl acetate fraction was subject to column chromatography yielding two phenolic compounds in the process, which were p-hydroxybenzoic acid and vanillic acid with good antioxidant activities. It was concluded that the seeds of papaya and these compounds might be useful as natural antioxidants. These findings were in agreements with subsequent studies i.e. report of Maisarah et al., (2013). Maisarah et al., (2013) conducted a comparative study on the total antioxidant activity (TAA), total phenolic content (TPC) and total flavonoid content (TFC) of different parts of papaya tree which consists of their ripe and unripe fruit, seeds and their young leaves (Table 8). Results showed highest antioxidant activity through $\beta$-carotene bleaching assay in unripe fruit $(90.67 \pm 0.29 \%)$ followed by its young leaves, ripe fruits and the seeds in that order. Young leaves exhibited a significant higher scavenging effect compared to other plant part and dose required in reducing the absorbance of DPPH control solution by $50 \%$ (EC50) were calculated at $1.0 \pm 0.08 \mathrm{mg} / \mathrm{ml}$. The EC50 values obtained were $4.3 \pm 0.01 \mathrm{mg} / \mathrm{ml}, 6.5 \pm 0.01 \mathrm{mg} / \mathrm{ml}$ and 7.8 $\pm 0.06 \mathrm{mg} / \mathrm{ml}$ for unripe fruit, ripe fruit and seeds respectively. Interestingly, it was discovered that that young leaf have the highest antioxidant content (424.89 \pm $0.22 \mathrm{mg}$ GAE/ $100 \mathrm{~g}$ dry weight and $333.14 \pm 1.03 \mathrm{mg}$ rutin equivalent/ $100 \mathrm{~g}$ dry weight, respectively). Statistically, Pearson correlation showed there were positive correlations between TPC and TFC with antioxidant activity assayed by DPPH radical scavenging assay ( $\mathrm{r}=0.846$ and $\mathrm{r}=0.873$, respectively). However correlation between TPC and TFC with $\beta$-carotene bleaching activity was not established. In brief, taken into account all the parameters measured, it was concluded that antioxidants were highly remarkable in the sequence of young leaves $>$ unripe fruit $>$ ripe fruit $>$ seed and recommended further investigation for the isolation and identification of the phytoconstituents responsible for antioxidant activity. The seeds of Carica papaya are a promising source of antioxidants, which may have therapeutic implications and the production of functional foods and nutraceutical in the near future.

The leaves of Carica papaya are generally considered waste but their extract is been linked with various health benefits (Quang et al. 2013). The leaves are rich in polyphenols which are said to be the reason for it's antioxidant properties. In a study by Quang et al. (2013), polyphenols were extracted from the leaves in an optimise extraction process. Varying temperature, extraction time and water-to-leaf ratios were observed to have significant effects on the extracted polyphenol yield as well as the scavenging and total antioxidant activities. Optimal extraction conditions derived for this process was $70 \circ \mathrm{C}$ for $20 \mathrm{~min}$, with a water-to-leaf ratio of $100: 7.5 \mathrm{~mL} / \mathrm{g}$. Water for extraction of the antioxidants component was considered safe and proposed for the extraction of the polyphenols in these leaves. A method to prepare crude powder from the leaves was also developed. Free radical scavenging activities and antioxidant activities of Carica papaya leaves extracts are shown in Figure 4.

Table 8 Antioxidant activity of selected part of Carica papaya*

\begin{tabular}{l|ccc}
\hline \multicolumn{1}{c}{ Papaya plant } & $\begin{array}{c}\text { DPPH EC50 } \\
(\mathrm{mg} / \mathrm{ml})\end{array}$ & $\begin{array}{c}\text { Phenol } \\
\text { (mg GAE/100g dry weight) }\end{array}$ & $\begin{array}{c}\text { Flavonoid } \\
\text { (mg GAE/100g dry weight) }\end{array}$ \\
\hline Ripe & $6.5 \pm 0.01$ & $272.66 \pm 1.53$ & $92.95 \pm 7.12$ \\
Unripe & $4.3 \pm 0.01$ & $339.91 \pm 9.40$ & $53.44 \pm 6.63$ \\
Seed & $1.0 \pm 0.08$ & $30.32 \pm 6.90$ & $59.54 \pm 12.23$ \\
Leaves & $7.8 \pm 0.06$ & $424.89 \pm 0.22$ & $333.14 \pm 11.02$ \\
\hline
\end{tabular}

*(Source: Maisarah et al., 2013) 


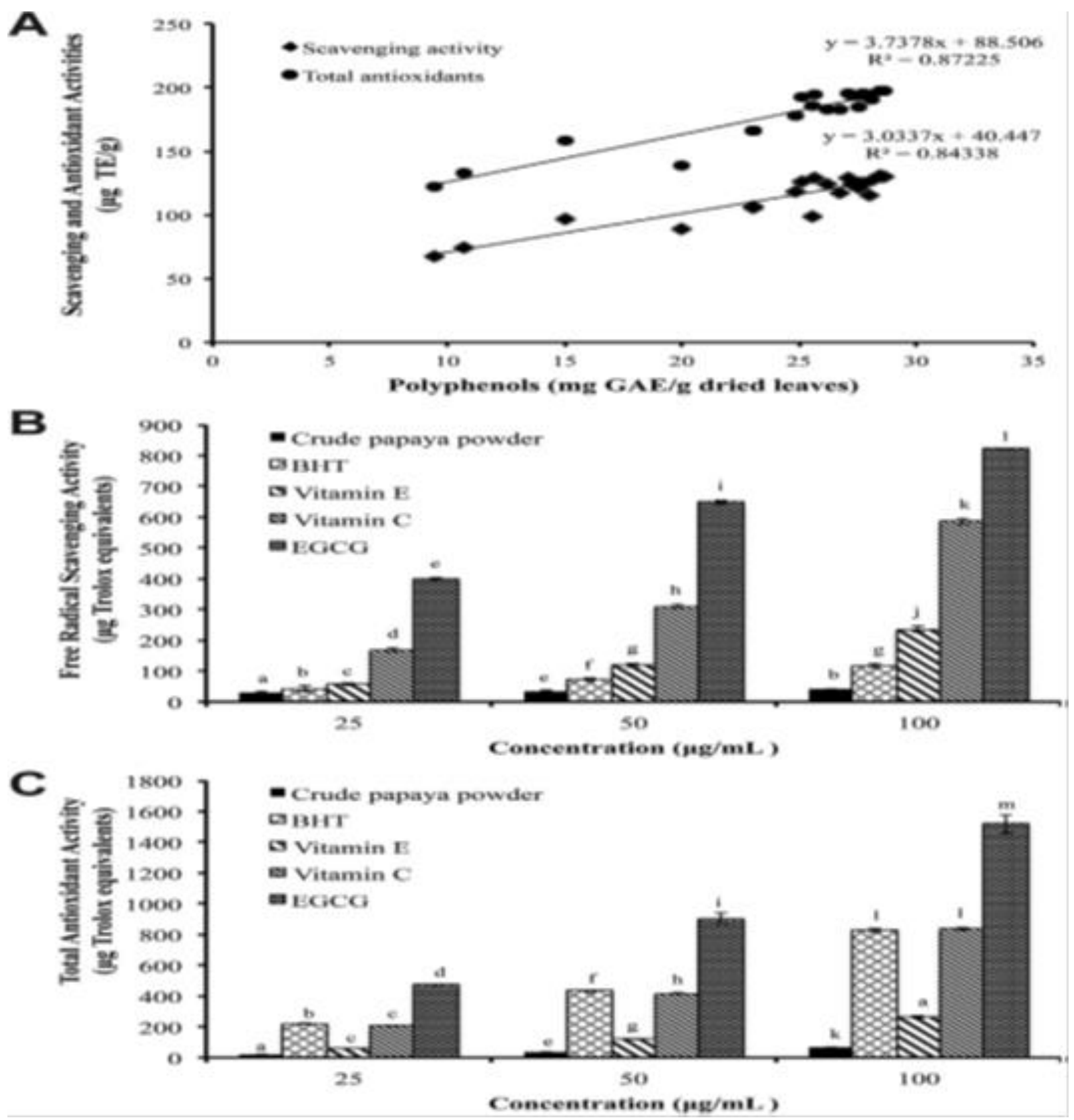

Figure 4 Radical scavenging and antioxidant activity of Carica papaya leaf powder, Source: Quang et al. 2013

\section{Antimicrobial Property}

The quest for suitable and affordable alternatives in the face of increasing antimicrobial drug resistance has led researchers into exploring the use of plant extracts in the treatment of infections (Akujobi et al., 2010). The fruit, seeds, leaves and peels of Carica papaya have been shown to exert an antimicrobial effect on the potentially dangerous microorganism. Carica papaya seed extract was observed to exert antimicrobial activity against Trichomonas vaginalis though care was suggested when using the seed extract for urinogenital disorders due to its toxicity (Calzada et al., 2007). Osato et al. (1993) reported the seed and pulp to showed bacteriostatic properties against several enteropathogens such as Bacillus subtilis, Salmonella typhi, Staphylococcus aureus, Proteus vulgaris, Pseudomonas aeruginosa and Klebiella pneumonia. Crushed papaya seeds were also found to exhibit clinical potential on Conjugal R plasmid transfer from Salmonella typhimurium and Escherichia coli in vitro and in vivo of genotobiotic mice (Vieira et al., 2001; Leite et al., 2005) and inhibitory effect against microbes isolated from infected wounds ( Akujobi et al., 2010). In an earlier study by usha'u et al. (2009) on the in-vitro sensitivity pattern of some urinary tract isolates to Carica papaya extracts, ethanol extract of the leaf was observe to be active against Escherichia coli and Klebsiella pneumonia $(7 \mathrm{~mm}$ each) at $1000 \mu \mathrm{g} / \mathrm{disc}$ concentration while chloroform and water fractions of the leaf were active against Escherichia coli, Klebsiella 
pneumonia and Proteus mirabilis at $1000 \mu \mathrm{g} / \mathrm{disc}$ concentration with zone diameter of $7 \mathrm{~mm}$ each though no effect was observes on P. aeruginosa. Carica papaya could find usefulness in the production of drugs against organisms causing urinary tract infections (Usha'u et al. 2009). In studies by Jyotsna et al .(2014), aqueous as well as the methanolic extract of Carica papaya seeds were effective in inhibiting bacterial pathogens while in contrast, chloroform extract of same plant leaves showed no effect against bacteria pathogens and the aqueous leaf extract was potent to inhibit them. Acetone leaf extracts exerted pronounced antibacterial effect on gram negative bacteria especially Pseudomonas

Species, a wound infection-causing pathogens. The extracts were also observed to contains active antimicrobial compounds which inhibit the growth of wound infection- causing pathogens in in vitro conditions (Aruljothi et al., 2014). It was suggested that the observed antimicrobial properties of the leaves might be the science behind the topical application of papaya leaf extracts to treat wound infection in traditional practice. The presences of bioactive substances have been reported to confer resistance to plants against bacteria, fungi and pest. Studies by Marshall et al. (2014) reports Carica papaya plant to contains bioactive compounds such as alkaloids, flavonoids, saponins and tannins which were attributed to their antimicrobial effects. The antimicrobial activity of the leaf extracts also had effects against S. aureus, E. coli, S. typhi, P. aeroginosa, and C. albican respectively, an observation which affirms recent reports of Subramanian et al. (2014) and Islam et al. (2015).

Carica papaya latex is effective against Grampositive and Gram- negative bacterial (Islam et al. 2015). The antagonistic activities of the fruit latex against some bacterial species were suggested to be due to some important inimical secondary metabolites presence. Natural bioactive products presence could as well be a lead in the development of novel pharmaceutical products for use against bacterial infection (Islam et al. 2015). From the results of the various studies on the antimicrobial effects of Carica papaya, it may as well be recommended as an alternative to chemotherapeutic agents as well in the production of new antimicrobial drugs which will be cost- effective.

\section{Anthelmintic Property}

Anthelmintic activity of papaya seed had been predominantly attributed to carpaine (an alkaloid) and carpasemine, later identified as benzyl thiourea (Boshra and Tajul, 2013). Pharmacological reports show that papaya seeds contain benzilsothiocyanate; an anthelmintic bio-substance (Kermanshai et al., 2001; Osato et al., 1993). Consumption of papaya seed is cheap, natural, harmless, readily available, mono-therapeutic, and can prevent against intestinal parasitosis which is a cheap medical alternative in tropical communities (Okeniyi et al., 2007; Saran and Ravish, 2013).

\section{Medicinal and Pharmaceutical Benefits}

Besides it nutritional contents, pawpaw plant has been proven to be medicinal and pharmacological useful which was reported to be due specific enzymes, antioxidants abilities and bioactive compounds present. It could well be referred to as a nutraceutical plant as it uses extends beyond it nutritional values (Fig.5). The wide range of enzymes, vitamins, phytochemicals, polyphenols compounds, bioactive compounds present in Carica papaya makes it a nutraceutical as well as a medicinal plant (Fig. 6).

There is evidence that Carica papaya leaves reduce symptoms of asthma, worming and dysentery (Runnie et al., 2004, Otusuki et al., 2010). Moreover, papaya leaf extracts have long been used as a remedy for cancer and infectious diseases by medical and traditional care givers in Africa and another part of the world (Otusuki et al., 2010: Kadiri, 2015). The aqueous leaf extract had been observing to accelerates wound healing (Mahmood et al ., 2005, Corral-Aguay et al., 2008), while the methanol extract has been reported to exhibit vasodilating and antioxidant effects, both of which are associated with cardiovascular risk reduction (Runnie et al., 2004). Besides their hypoglycemic properties (Andrade-Cetto et al., 2005; Isela et al., 2012,2014), different parts of C. papaya are used in Mexican and African folk medicine to treat various diseases such as diarrhoea, inflammation and diabetes (Corral-Aguayo et al.,2009, Chávez-Quintal et al., 2011; Kadiri, 2015). Aqueous extract of papaya leaves in an unrevealed composition possess anticancer activity and inhibit cell proliferation in a variety of cancer cell lines, which had been patent by Morimoto et al. (2008). Likewise, the aqueous extract exerts antitumor activity and immunomodulatory activity in tumour cell lines and it proved up-regulation of immunomodulatory genes by microarray studies (Otsuki et al. 2010).

There has been reported treatment of dengue fever using the leaf extract of this plant (Subenthiran et al., 2013). Also, reported the effect of the leaves and seeds extracts on cancer bacterial infection, anti-inflammation effects, anti-sickling, inhibitory plasmodium activities as well as in the management of sickle-cell anaemia, Aedes Aegypti, HIV, heart diseases, gastrointestinal disorders and diabetics conditions have been reported (Table 9). Papain, a by-product of papaya fruits, peel, leaves and latex have been utilised for beer clarification and meat tenderization in Central America (Feng, 2014). Papain and other endopeptidases have several medical benefits, such as defibrinating wounds and treatment of oedemas (Nitsawang et al., 2006). A study by Starley et al., (1999) reported some specific antimicrobial substrates such as carpaine and aglycones as been present in papaya which can be beneficial to health. Oyoyede (2005) reported the extract of papaya fruits and seeds to have antibacterial activity against Staphylococcus aureus, Bacillus cereus, Esherischia coli, Pseudomanas, aeruginosa and Shigella flexneri. Furthermore, papaya fruits have been applied in several medical uses such as the relief of nervous pains and elephantoid growth (Feng, 2014). 
Seeds

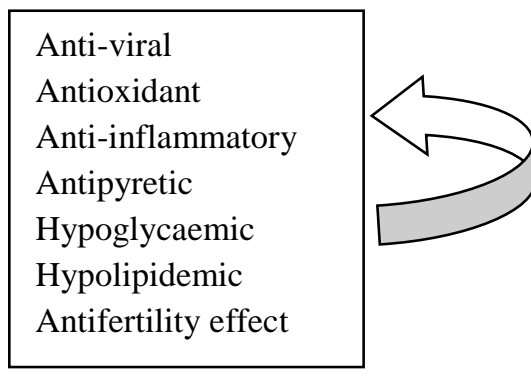

Latex

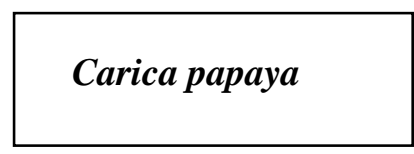

Leaves

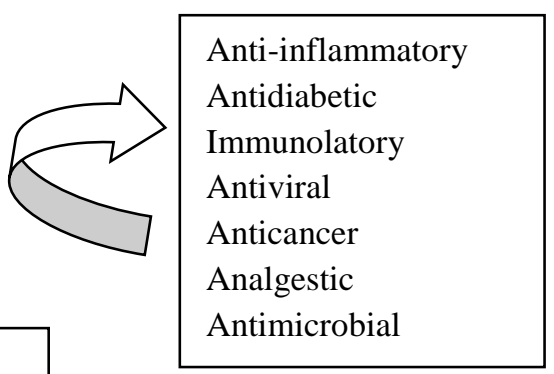

Fruits\& aerial part parts

\section{Inflammation Antibacterial Wound healing}
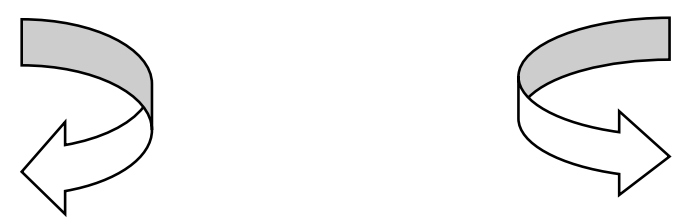

Anti-cancer

Wound healing

Antioxidant

Nintriant

Figure 5 Medicinal and pharmaceutical properties of Carica papaya

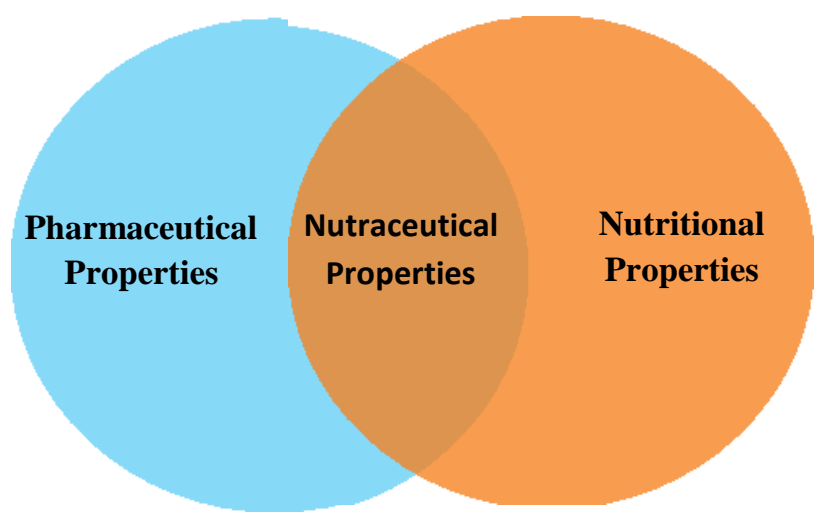

Figure 6 Nutraceutical potential properties of pawpaw

\section{Hepatoprotective Activity}

The liver is the largest organs in the human body and disease to it have been reported to be a major cause of death worldwide. Aqueous leaf extract of Carica papaya as medicine in the treatment of some forms of liver diseases traditionally is a common practice in the south western part of Nigeria and some other part of Africa. Based on perceiving use of the leaves and seeds of these plant in the treatment of liver related disease and oral safety on acute safety, a number of studies have been conducted in recent times to validate or invalidate these claims. In studies by Pandit et al. (2013), Carica papaya leaves extracts had an ameliorative effect on drug-induced hepatotoxicity. Hepatoprotective activity of leaves of Carica papaya was evident by significant reduction in levels of all serum markers in both experimenter models. Extracts significantly increased levels of superoxide dismutase, glutathione and total protein with the corresponding decrease in the levels of thiobarbituric acid reactive substance and corresponding improvements in the histopathology of liver. The study concludes by stating that the leaves of Carica papaya possess hepatoprotective activity, which may be partly due to its antioxidant effect. It was also suggested that Carica papaya leaves are promising plants for the development of phytomedicine which could find application in herbal formulations alone or in combination with other hepatoprotective drugs aid in the treatment of liver ailments. Observations of these studies agrees with a previous report by Mohammed et al .(2011) on the hepatoprotective effect of aqueous leaf extract of Carica papaya against CCL4-induced hepatic damage in rats in which improvements in CCl4-induced hepatic histological changes were observed on administration of aqueous leaf extract of Carica papaya at an oral dose of 400 $\mathrm{mg} / \mathrm{kg} / \mathrm{day}$. Likewise, aqueous extracts of the seeds have been reported to revert carbon tetrachloride induced hepatotoxicity in rats (Adeneye et al. 2009). The hepatoprotective roles of the leaves and seeds of Carica papaya are no more in doubts and these scientific findings validate the use of the extracts of these plant parts by local folks in the treatment of liver disease. 
Table 9 Therapeutics studies and findings on Carica papaya plant parts

\begin{tabular}{|c|c|c|c|c|c|}
\hline Plant part & Research aim & Test & Extracts & Observation/ findings & Ref \\
\hline Leaf & $\begin{array}{l}\text { Therapeutic potential of } \\
\text { Carica papaya leaf extracts in } \\
\text { treatment of Dengue patients }\end{array}$ & $\begin{array}{l}\text { Haemoglobin, RBC, PCV, Total } \\
\text { WBC count, Platelet count, ESR, } \\
\text { Lymphocytes, Neutrophils, } \\
\text { Eosinophils, Monocytes, Serum } \\
\text { Creatinine, Total Bilirubin, Direct } \\
\text { Bilirubin }\end{array}$ & $\begin{array}{l}\text { Aqueous } \\
\text { extracts with } \\
\text { added sucrose }\end{array}$ & $\begin{array}{l}\text { Recovering of patients } \\
\text { from dengue infection } \\
\text { upon administration of } \\
\text { leaf extracts }\end{array}$ & $\begin{array}{l}\text { Sai Gopal et } \\
\text { al., } 2015\end{array}$ \\
\hline Latex & $\begin{array}{l}\text { Evaluation Of antibacterial } \\
\text { activities Of crude latex of } \\
\text { Carica papaya }\end{array}$ & $\begin{array}{l}\text { Disk diffusion assays for } \\
\text { antimicrobial activity }\end{array}$ & $\begin{array}{l}\text { Methanolic } \\
\text { extracts }\end{array}$ & $\begin{array}{l}\text { Noticeable inhibition of } \\
\text { bacterial growth against } \\
\text { the tested organisms. }\end{array}$ & $\begin{array}{l}\text { Islam et al., } \\
2015\end{array}$ \\
\hline Leaf & $\begin{array}{l}\text { Antimicrobial screening and } \\
\text { phytochemical analysis of } \\
\text { Carica papaya leaf extracts }\end{array}$ & $\begin{array}{l}\text { Disc diffusion technique for } \\
\text { antimicrobial screening test }\end{array}$ & $\begin{array}{l}\text { Ethanol and } \\
\text { aqueous } \\
\text { extracts }\end{array}$ & $\begin{array}{l}\text { Plant extracts showed } \\
\text { significant antimicrobial } \\
\text { effects and can be used as } \\
\text { an alternative to the } \\
\text { antibiotics }\end{array}$ & $\begin{array}{l}\text { Marshall et } \\
\text { al., } 2015\end{array}$ \\
\hline $\begin{array}{l}\text { Seed \& } \\
\text { Peel }\end{array}$ & $\begin{array}{l}\text { Effects of the aqueous } \\
\text { extracts of the seed and peel } \\
\text { of Carica Papaya against } \\
\text { Aedes Aegypti }\end{array}$ & $\begin{array}{l}\text { Alkaloid content, tannin content, } \\
\text { flavonoid content, mosquito } \\
\text { culture, larvicidal activity }\end{array}$ & $\begin{array}{l}\text { Aqueous } \\
\text { extracts }\end{array}$ & $\begin{array}{l}\text { Aqueous extracts of seed } \\
\text { and peel of Carica papaya } \\
\text { showed potential } \\
\text { larvicidal activity for } \\
\text { Aedes Aegypti. }\end{array}$ & $\begin{array}{l}\text { Lisda et al., } \\
2015\end{array}$ \\
\hline Seed & $\begin{array}{l}\text { Hydro-Methanol extract of } \\
\text { ripe Carica Papaya Seed and } \\
\text { its relationship with Albino } \\
\text { Wistar Rats' Liver Histology }\end{array}$ & Acute toxicity test & $\begin{array}{l}\text { Hydromethanol } \\
\text { extract }\end{array}$ & $\begin{array}{l}\text { Hydromethanol seed } \\
\text { extract of Carica papaya } \\
\text { (HESC) is hepatotoxic in } \\
\text { a time and dose-dependent } \\
\text { manner and the } \\
\text { hepatotoxicity of HSEC is } \\
\text { reversible. }\end{array}$ & $\begin{array}{l}\text { Paul and } \\
\text { Ligha, } 2015\end{array}$ \\
\hline Seed & $\begin{array}{l}\text { To scientifically verify the } \\
\text { claims of our traditional } \\
\text { healers on the anti- } \\
\text { inflammatory activity of } \\
\text { Carica papaya and possibly } \\
\text { deduce its activities }\end{array}$ & $\begin{array}{l}\text { Animal experiment: } \mathrm{LD}_{50} \text { Study, } \\
\text { animal experiment ,anti- } \\
\text { inflammatory study, } \\
\text { photochemistry test }\end{array}$ & $\begin{array}{l}\text { Methanolic } \\
\text { extract }\end{array}$ & $\begin{array}{l}\text { All doses of extract } \\
\text { showed a dose and time } \\
\text { dependent inhibition } \\
\text { effects of oedema } \\
(\mathrm{P}<0.05) \text {. The anti- } \\
\text { inflammatory activity of } \\
\text { the seeds of Carica } \\
\text { papaya was perhaps } \\
\text { proven. }\end{array}$ & $\begin{array}{l}\text { Amazu et al., } \\
2014\end{array}$ \\
\hline Leaf & $\begin{array}{l}\text { Thrombocytosis ,anti- } \\
\text { inflammatory properties, and } \\
\text { toxicological evaluation of } \\
\text { Carica papaya Mature Leaf } \\
\text { concentrate in a Murine } \\
\text { Model }\end{array}$ & $\begin{array}{l}\text { Clinical assessment, } \\
\text { thrombocytopenia evaluation, } \\
\text { acute toxicity test, phytochemical } \\
\text { screening }\end{array}$ & $\begin{array}{l}\text { Leaf } \\
\text { concentrate } \\
\text { from freshly } \\
\text { crushed leaf of } \\
\text { Carica papaya }\end{array}$ & $\begin{array}{l}\text { freshly prepared mature } \\
\text { leaf concentrate of C } \\
\text { papaya is orally active and } \\
\text { effectively increases rat } \\
\text { platelet, WBC and RBC } \\
\text { count with no acute } \\
\text { toxicity, and possesses } \\
\text { potent anti-inflammatory } \\
\text { activity, that overly } \\
\text { justifies claims of } \\
\text { traditional medicine. }\end{array}$ & $\begin{array}{l}\text { Gammulle et } \\
\text { al., } 2012\end{array}$ \\
\hline Leaf & $\begin{array}{l}\text { Analgesic activity of Carica } \\
\text { papaya leaves (CPL) in mice } \\
\text { model using acetic acid- } \\
\text { induced pain (Siegmund } \\
\text { method) }\end{array}$ & $\begin{array}{l}\text { Animal experiment, } \\
\text { phytochemical analysis, acetic } \\
\text { acid-induced writhing method }\end{array}$ & $\begin{array}{l}\text { n-hexane, ethyl } \\
\text { acetate, ethanol } \\
\text { extracts fraction }\end{array}$ & $\begin{array}{l}\text { n-hexane, ethyl acetate and } \\
\text { ethanol of Carica papaya } \\
\text { leaves extracts dose of } \\
0.175 ; 0.35 ; 0.70 \mathrm{mg} / \mathrm{kg} \\
\text { bw for each extract offered } \\
\text { some protection against } \\
\text { acetic acid-induced } \\
\text { visceral pain }\end{array}$ & $\begin{array}{l}\text { Hasimun et } \\
\text { al.. } 2014\end{array}$ \\
\hline Leaf & $\begin{array}{l}\text { Antimicrobial Properties of } \\
\text { Carica papaya (Papaya) } \\
\text { Different Leaf Extract against } \\
\text { E. coli, S. aureus and C. } \\
\text { albicans }\end{array}$ & $\begin{array}{l}\text { Disc diffusion technique and } \\
\text { poisons plate method for } \\
\text { antimicrobial assay. Reduce } \\
\text { antioxidant power, phytochemical } \\
\text { analysis }\end{array}$ & $\begin{array}{l}\text { Chloroform, } \\
\text { ethanol, ethyl } \\
\text { acetate and } \\
\text { methanol } \\
\text { solvents. }\end{array}$ & $\begin{array}{l}\text { Extracts fraction } \\
\text { demonstrate antimicrobial } \\
\text { effects against tested } \\
\text { microbes with methanol } \\
\text { extract showing higher } \\
\text { inhibition against S. aureus } \\
\text { than E. coli and C. } \\
\text { albicans. }\end{array}$ & $\begin{array}{l}\text { Subramanian } \\
\text { et al., } 2014\end{array}$ \\
\hline Leaf & $\begin{array}{l}\text { Antibacterial activity of } \\
\text { Carica Papaya leaf extracts } \\
\text { against wound infection- } \\
\text { causing bacteria }\end{array}$ & $\begin{array}{l}\text { Agar well diffusion method for } \\
\text { antimicrobial activity }\end{array}$ & $\begin{array}{l}\text { Aqueous } \\
\text { solvents, } \\
\text { methanol } \\
\text { solvents, } \\
\text { acetone } \\
\text { solvents }\end{array}$ & $\begin{array}{l}\text { All extracts prepared from } \\
\text { leaf (acetone, water, and } \\
\text { methanol) exhibited } \\
\text { highest antibacterial } \\
\text { activity against gram } \\
\text { negative organism. }\end{array}$ & $\begin{array}{l}\text { Aruljothi et } \\
\text { al., } 2014\end{array}$ \\
\hline
\end{tabular}




\begin{tabular}{|c|c|c|c|c|c|}
\hline Leaf & $\begin{array}{l}\text { Effect of Carica papaya leaf } \\
\text { extract on blood chemistry } \\
\text { specifically thrombocyte } \\
\text { count of rats }\end{array}$ & $\begin{array}{l}\text { Animal experiments, } \\
\text { haematological and serological } \\
\text { analysis }\end{array}$ & Leaf extract & $\begin{array}{l}\text { C. papaya leaf extract was } \\
\text { associated with rapid } \\
\text { increase of blood platelet }\end{array}$ & $\begin{array}{l}\text { Sheikh et al., } \\
2014\end{array}$ \\
\hline Seed & $\begin{array}{l}\text { Hypoglycemic and } \\
\text { hypolipidemic activities of the } \\
\text { aqueous seed extract of } \\
\text { Carica papaya Linn. in } \\
\text { Wistar rats }\end{array}$ & $\begin{array}{l}\text { Phytochemical analyses, acute } \\
\text { oral toxicity testing, blood } \\
\text { collection and bioassays }\end{array}$ & $\begin{array}{l}\text { Aqueous } \\
\text { extracts }\end{array}$ & $\begin{array}{l}\text { Results showed that } \\
\text { Carica papaya extracts } \\
\text { significantly and } \\
\text { progressively ( }<<0.05 \text {, } \\
\mathrm{p}<0.01 \text { and } \mathrm{p}<0.001) \\
\text { lowered the fasting blood } \\
\text { sugar, serum triglyceride, } \\
\text { total cholesterol, low- } \\
\text { density lipoprotein } \\
\text { cholesterol, and very low- } \\
\text { density lipoprotein } \\
\text { cholesterol dose- } \\
\text { dependently. }\end{array}$ & $\begin{array}{l}\text { Adeneyea } \\
\text { and } \\
\text { Olagunjub, } \\
2009\end{array}$ \\
\hline Seed & $\begin{array}{l}\text { Antioxidant Effect of Carica } \\
\text { papaya Seeds Water Extract }\end{array}$ & $\begin{array}{l}\text { Cell Cultures and treatments, cell } \\
\text { viability and morphology, } \\
\text { catalase Activity, HSP-70, } \\
\text { cytochrome C quantification, } \\
\text { antioxidant activity }\end{array}$ & $\begin{array}{l}\text { Aqueous } \\
\text { extract }\end{array}$ & $\begin{array}{l}\text { C. papaya seeds protect } \\
\text { fibroblasts from } \mathrm{H}_{2} \mathrm{O}_{2-} \\
\text { induced stress due to the } \\
\text { antioxidant activity of the } \\
\text { water extract. Non-edible } \\
\text { parts of C. papaya, in } \\
\text { particular, seeds water } \\
\text { extract, may be a } \\
\text { promising source of } \\
\text { antioxidants, which may } \\
\text { have therapeutic } \\
\text { implications }\end{array}$ & $\begin{array}{l}\text { Elisa et al., } \\
2014\end{array}$ \\
\hline Seed & $\begin{array}{l}\text { Potency of aqueous extract of } \\
\text { Carica papaya seeds as an } \\
\text { anti-inflammatory, antipyretic } \\
\text { and antinociceptive in animal } \\
\text { models }\end{array}$ & $\begin{array}{l}\text { Writhing method, tail immersion } \\
\text { method, xylene-induced ear } \\
\text { oedema test and Carrageenan-- } \\
\text { induced paw oedema }\end{array}$ & $\begin{array}{l}\text { Aqueous crude } \\
\text { extracts }\end{array}$ & $\begin{array}{l}\text { Aqueous extract of Carica } \\
\text { papaya seed extract has } \\
\text { minimal anti-inflammatory } \\
\text { and antinociceptive } \\
\text { activities with the tested } \\
\text { doses in the used animal } \\
\text { models, but a better } \\
\text { antipyretic activity. }\end{array}$ & $\begin{array}{l}\text { Umana et al., } \\
2014\end{array}$ \\
\hline Seed & $\begin{array}{l}\text { Effect of aqueous seed extract } \\
\text { of Carica papaya Linn on } \\
\text { carbon tetrachloride induced } \\
\text { hepatotoxicity in rats }\end{array}$ & $\begin{array}{l}\text { Animal experiment, experimental } \\
\text { induction of CCl4 hepatotoxicity } \\
\text { blood collection and biochemical } \\
\text { assays, histopathological studies } \\
\text { of rat livers }\end{array}$ & $\begin{array}{l}\text { Aqueous } \\
\text { extracts }\end{array}$ & $\begin{array}{l}\text { Biochemical results } \\
\text { obtained were } \\
\text { corroborated by } \\
\text { improvements in the CCl4- } \\
\text { induced hepatic } \\
\text { histological changes }\end{array}$ & $\begin{array}{l}\text { Adeneye et } \\
\text { al., } 2009\end{array}$ \\
\hline $\begin{array}{l}\text { Ripe and } \\
\text { unripe } \\
\text { papaya } \\
\text { leaves and } \\
\text { seed }\end{array}$ & $\begin{array}{l}\text { Analysis of Different Parts of } \\
\text { Carica Papaya }\end{array}$ & $\begin{array}{l}\text { Proximate analysis, antioxidant } \\
\text { and antiproliferative activities }\end{array}$ & $\begin{array}{l}\text { Aqueous } \\
\text { methanolic } \\
\text { extracts }\end{array}$ & $\begin{array}{l}\text { Results obtained from } \\
\text { cytotoxic activities showed } \\
\text { that MCF-7 (hormone- } \\
\text { dependent breast cancer) } \\
\text { and MDA-MB-231 (non- } \\
\text { hormone dependent breast } \\
\text { cancer) cell cultures were } \\
\text { significantly inhibited by } \\
\text { the extract. }\end{array}$ & $\begin{array}{l}\text { Maisarah et } \\
\text { al., (2014) }\end{array}$ \\
\hline Leaf & $\begin{array}{l}\text { Antioxidant and anticancer } \\
\text { capacity of saponin-enriched } \\
\text { Carica papaya leaf extracts }\end{array}$ & $\begin{array}{l}\text { Antioxidant, free radical } \\
\text { scavenging and ion-reducing } \\
\text { capacity, total phenolic } \\
\text { compounds, pancreatic cell } \\
\text { viability }\end{array}$ & $\begin{array}{l}\text { Aqueous and } \\
\text { ethanolic } \\
\text { extracts }\end{array}$ & $\begin{array}{l}\text { The study revealed that the } \\
\text { PL contains numerous } \\
\text { bioactive compounds, with } \\
\text { significant anticancer } \\
\text { activity }\end{array}$ & $\begin{array}{l}\text { Vuong et } \\
\text { al.,(2015) }\end{array}$ \\
\hline $\begin{array}{l}\text { Seed and } \\
\text { peel }\end{array}$ & $\begin{array}{l}\text { Evaluation of the antioxidant } \\
\text { potential of Carica papaya } \\
\text { peels and seed }\end{array}$ & $\begin{array}{l}\text { Total phenolic content } \\
\text { (TPC,DPPH radical scavenging } \\
\text { ability, ferric } \\
\text { reducing/antioxidant power } \\
\text { (FRAP), and ABTS radical } \\
\text { cation inhibition activity }\end{array}$ & $\begin{array}{l}\text { Aqueous } \\
\text { extracts and } \\
\text { acetone extract }\end{array}$ & $\begin{array}{l}\text { Papaya peel and seed } \\
\text { extracts demonstrated } \\
\text { potent antioxidant activity } \\
\text { to a certain extent and } \\
\text { could be of nutraceutical } \\
\text { importance for food } \\
\text { industry application. }\end{array}$ & $\begin{array}{l}\text { Yee et al., } \\
2012\end{array}$ \\
\hline
\end{tabular}




\begin{tabular}{|c|c|c|c|c|c|}
\hline Leaf & $\begin{array}{l}\text { The platelet increasing } \\
\text { property of Carica papaya } \\
\text { leaves juice (CPLJ) in } \\
\text { patients with dengue fever } \\
\text { (DF). }\end{array}$ & $\begin{array}{l}\text { Human experiment, blood } \\
\text { collection and bioassays, gene } \\
\text { expression studies }\end{array}$ & Juice & $\begin{array}{l}\text { Carica papaya leaves juice } \\
\text { significantly increase the } \\
\text { platelet count in patients } \\
\text { with dengue fever and } \\
\text { dengue haemorrhagic } \\
\text { fever }\end{array}$ & $\begin{array}{l}\text { Subenthiran } \\
\text { et al., } 2013\end{array}$ \\
\hline Leaf & Biochemical constituents & $\begin{array}{l}\text { Minerals determination, } \\
\text { Proximate determination }\end{array}$ & - & $\begin{array}{l}\text { C. papaya has the high } \\
\text { potentiality for curing a } \\
\text { number of diseases. }\end{array}$ & $\begin{array}{l}\text { Suhas et al., } \\
2014\end{array}$ \\
\hline $\begin{array}{l}\text { Seed and } \\
\text { Leaf }\end{array}$ & $\begin{array}{l}\text { Antibacterial Activity of Seed } \\
\text { and Leaf Extract of Carica } \\
\text { Papaya var. Pusa dwarf Linn }\end{array}$ & $\begin{array}{l}\text { Agar well diffusion assay for } \\
\text { antimicrobial activity }\end{array}$ & $\begin{array}{l}\text { Aqueous and } \\
\text { methanolic } \\
\text { extracts }\end{array}$ & $\begin{array}{l}\text { Aqueous, as well as the } \\
\text { methanolic extract of } \\
\text { seeds, were effective to } \\
\text { inhibit the bacterial } \\
\text { pathogens }\end{array}$ & $\begin{array}{l}\text { Jyotsna et } \\
\text { al., (2014) }\end{array}$ \\
\hline Seed & $\begin{array}{l}\text { Antinociceptive and anti- } \\
\text { inflammatory effects of the } \\
\text { methanol seed extract of } \\
\text { Carica papaya in mice and } \\
\text { rats }\end{array}$ & $\begin{array}{l}\text { Animal experiments, Brine } \\
\text { shrimps lethality test, acetic acid- } \\
\text { induced abdominal writhing, } \\
\text { pentobarbitone-induced narcosis, } \\
\text { formalin-induced nociception, } \\
\text { carrageenin-induced paw oedema }\end{array}$ & $\begin{array}{l}\text { Methanol } \\
\text { extracts }\end{array}$ & $\begin{array}{l}\text { Carica papaya contains } \\
\text { potent bioactive } \\
\text { compounds which showed } \\
\text { antinociceptive effect } \\
\text { probably mediated } \\
\text { centrally and peripherally, } \\
\text { and also involving mild } \\
\text { anti-inflammatory } \\
\text { mechanisms }\end{array}$ & $\begin{array}{l}\text { Anaga and } \\
\text { Onehi, } 2010\end{array}$ \\
\hline Root & $\begin{array}{l}\text { Antibacterial activity of root } \\
\text { extracts of Carica papaya L. }\end{array}$ & $\begin{array}{l}\text { Phytochemical screening, cup } \\
\text { plate agar diffusion method for } \\
\text { Antimicrobial Activity }\end{array}$ & $\begin{array}{l}\text { Aqueous and } \\
\text { methanolic } \\
\text { extracts }\end{array}$ & $\begin{array}{l}\text { Methanol extracts } \\
\text { demonstrate the highest } \\
\text { activity against test } \\
\text { bacteria as antibacterial } \\
\text { agents in novel drugs }\end{array}$ & $\begin{array}{l}\text { Doughari et } \\
\text { al., } 2007\end{array}$ \\
\hline Fruit & $\begin{array}{l}\text { Antibacterial activity of } \\
\text { extracts of Carica papaya } \\
\text { (paw-paw) fruit }\end{array}$ & $\begin{array}{l}\text { Disc diffusion method for } \\
\text { antimicrobial activity, } \\
\text { phytochemical screening }\end{array}$ & $\begin{array}{l}\text { Aqueous } \\
\text { extracts, } 30 \% \\
\text { ethanolic } \\
\text { extracts }\end{array}$ & $\begin{array}{l}\text { Extracts demonstrated } \\
\text { antibacterial activity }\end{array}$ & $\begin{array}{l}\text { Akujobi et } \\
\text { al., } 2010\end{array}$ \\
\hline $\begin{array}{l}\text { Aerial } \\
\text { parts }\end{array}$ & $\begin{array}{l}\text { Anticancer Activity of } \\
\text { Carica papaya Extracts in } \\
\text { vitro and Phytochemical } \\
\text { Analysis }\end{array}$ & $\begin{array}{l}\text { Sulforhodamine B (SRB) assay, } \\
\text { Phytochemical analysis, }\end{array}$ & $\begin{array}{l}\text { Petroleum } \\
\text { ether, } \\
\text { Chloroform, } \\
\text { Ethyl acetate, } \\
\text { Methanol } 80 \%\end{array}$ & $\begin{array}{l}\text { petroleum extract of C. } \\
\text { papaya aerial parts has a } \\
\text { significant anticancer } \\
\text { effect on MCF7 (breast) } \\
\text { cancer cells }\end{array}$ & $\begin{array}{l}\text { Khaled and } \\
\text { Gerda, } 2013\end{array}$ \\
\hline
\end{tabular}

\section{Antidiabetic Disease}

Diabetes mellitus is possibly the world's largest growing metabolic disorder and there has been surging interest in the last few decades in traditional plant treatment for diabetic patients (Isela et al., 2014). The difficulty of managing hyperglycaemia in diabetes is the most important factor in reducing the risks associated with diabetes and its complications (Polonsky, 2012). There are reports that describe the therapeutic effect of Carica papaya leaf on dengue and malaria (Ahmad et al., 2011) and as anti-inflammatory (Owoyele et al., 2008). Other reports suggest that fermented papaya preparation significantly reduces plasma glucose levels in healthy subjects and in patients with type 2 diabetes (Danese et al., 2006). The hypoglycaemic activities of Carica papaya have been previously described for its fruit and leaves (Aruoma et al., 2010) though available information regarding the leaves was said to be incomplete (Sasidharan et al., 2011). In a recent study, Isela et al., (2012, 2014) studied the phytochemicals of Carica papaya leaves, while also evaluating its hypoglycaemic effect in diabetic rats and streptozotocin-induced diabetic rats. The decrease in serum glucose, triglycerides and transaminases in diabetic rats were observed after administration of Carica papaya chloroform extract. In streptozotocin-induced diabetic rats, aqueous extract of Carica papaya significantly decreased blood glucose levels $(\mathrm{P}<0.05)$. It also causes significant decreased in cholesterol, triacylglycerol and amino-transferases blood levels. Though low plasma insulin levels did not change after treatment in diabetic rats, they were significantly increased in non-diabetic animals. Pancreatic islet cells were normal in non-diabetic treated animals, whereas in diabetic treated rats, the extracts help aids in islet manifestation and regeneration as the preservation of cell size. In the liver of diabetic treated rats, Carica papaya prevented hepatocyte disruption, as well as accumulation of glycogen and lipids. In summary, aqueous extract of $\mathrm{C}$. papaya exerted a hypoglycaemic and antioxidant effect which also improved the lipid profile of diabetic rats. These affirm the potential beneficial ability of Carica papaya to heals symptoms of diabetic though there is still need for further study using human subject.

Carica papaya seed extracts have been observed to exert anti-diabetic effects in studies conducted on laboratory animals. Hypoglycaemic and hypolipidemic activities of the aqueous seed extract of Carica papaya 
Linn in Wistar rats lowered significantly fasting blood glucose (FBS), serum triglyceride (TG), total cholesterol (TC), low-density lipoprotein cholesterol (LDL-c) and very low-density lipoprotein cholesterol (VLDL-c) in a dose-dependently pattern. The acute oral toxicity showed the seed extract to be safe while phytochemical analyses of the extracts revealed the presence of alkaloids, flavonoids, saponins, tannins, anthraquinones, anthocyanosides and reducing sugars. Reports on the leaves and seeds extracts lend support to its folkloric use in the management of suspected diabetic and diabetics patients.

\section{Conclusions}

The use of papaya extends beyond it fruit for food to other parts of the plant such as its seeds, leaves, peels and aerial parts for medicine and pharmacological purposes. The seed and leaves apart from reported pharmacological use has nutritional values which make it a potential raw material in the food industry. The nutritional value of the seed needs to research further and its application in food ingredient, fortification or production explore. Further investigation using cell culture studies, animal studies and clinical trials are needed to proving the nutritional, chemoprevention and therapeutic potential of different parts of papaya and to check the adverse effects if any in its use. Also, the nutritional, as well as the pharmacological properties of its seeds and leaves, need to be explored further with the aim of producing drug and food supplements with nutraceutical properties.

\section{References}

Adesuyi AO, Ipinmoroti KO. 2011. The Nutritional and Functional properties of the seed flour of three varieties of Carica papaya. Cur Res Chem 3(1): 70-75.

Adeneye AA, Olagunju, JA, Banjo AAF, Abdul SF, Sanusi OA, Sanni OO, Osarodion BA, Shonoiki, O.E. 2009. The aqueous seed extract of Carica papaya Linn. Prevents carbon tetrachloride induced hepatotoxicity in rats. Int J App Res Nat Prod 2(2): 19-32.

Adeneye AA, Olagunjub JA. 2009. Preliminary hypoglycemic and hypolipidemic activities of the aqueous seed extract of Carica papaya Linn in wistar rats. Bio Med (1):1-10.

Ahmad N, Fazal H, Ayaz M, Abbasi BH, Mohammad I and Fazal L. 2011. Dengue fever treatment with Carica papaya leaves extracts. Asian Pac j Trop Biomed 1: 330-333.

Akujobi CN, Ofodeme CA, and Enweani. 2010. Determination of anti-bacterial activity of Carica papaya (pawpaw) extracts. Nig J Clin Prac 13(1): 55-57.

Anaga AO, Onehi EV. 2010. Antinociceptive and anti-inflammatory effects of the methanol seed extract of Carica papaya in mice and rats. Afri J Phar Pharmaco 4(4): 140-144.

Ang YK, Sia WC, Khoo, HE and Yim, HS. 2012. Antioxidant Potential of Carica Papaya Peel and Seed. Focusing Mod Food Ind 1, 1.

Amazu LU, Azikiwe CCA, Njoku CJ, Osuala FN, Nwosu PJC, Ajugwo AO, Enye JC. 2014. Anti-inflammatory activity of the methanolic extract of the seeds of Carica papaya in experimental animals. Asian Pac J Trop Med 884-886. http://dx.doi.org/10.1016/S1995-7645(10)60212-X.

Aruljothi S, Uma C, Sivagurunathan P, Bhuvaneswari M. 2014. Investigation on antibacterial activity of Carica Papaya Leaf Extracts against Wound Infection-Causing Bacteria. Int J Res Studies Biosciences (2)11: 8-12.
Banerjee, A.K. and Banerjee, I. 1986. A survey of medicinal plants in shevaroy hills. J Econ taxonomic botany 8,271-290.

Bari LP, Hassen N, Absar ME, Haque MIIE, Khuda MM, Pervin SK and Hossain MI. 2006. Nutritional analysis of two varieties of papaya (Carica papaya) at different maturation stages. Pak J Bio Sci 9: 137-140.

Cassia RM, Mieko K, Neuza J. 2011. Characterization of a high oleic oil extracted from papaya (Carica papaya L.) seeds. Food Sci Tech Campinas, 31(4): 929-934.

Chávez-Quintal P, González-Flores T, Rodríguez-Buenfil I, Gallegos-Tintoré. 2011. Antifungal activity in ethanolic extracts of Carica papaya Linn Maradol leaves and seeds. Ind $\mathrm{J}$ Microbio 51: 54-60.

Claudia MS, Celeste, MPA, Juliana MF, Estela RQ, Marcelle MM. 2014. Chemical characterization of the flour of peel and seed from two papaya cultivars. Food Sci Tech Campinas 34 (2).

Corral-Aguayo RD, Yahia EM, Carrillo-López A, González-Aguilar G. 2008. Correlation between some nutritional components and the total antioxidant capacity measured with six different assays in eight horticultural crops. J Agric Food Chem 56: 10498 10504.

Doughari JH, Elmahmood AM, Manzara S. 2007. Antibacterial activity of root extracts of Carica papaya L. Afri J Microbio Res 037-041. http://www.academicjournals.org/ajmr.

Duke JA. 1996. Carica papaya Linn. Retrieved from http://www.hort.purdue.edu/newcrop/ duke_energy/Carica_papaya.html.

Elisa P, Majdi D, Stefania M, Cristian V, and Luciana D. 2014. Administration dependent antioxidant effect of Carica papaya seeds water extract. http://dx.doi.org/10.1155/2014/281508.

Feng S. 2014. Papaya. An M.sc Report. Food and Wine Science group, Lincoln University NZ. http://foodscience. wikispaces.com/

FAO. 2007. Food and Agricultural Organisation, United Nations statistics, online Website http://faostat.fao.org.

Gammulle A, Ratnasooriya, WD, Jayakody J, Charmain F, Chamini K, and Preethi V, Udagama. 2015. Thrombocytosis and antiinflammatory properties, and toxicological evaluation of Carica papaya mature leaf concentrate in a Murine Model. Online Int J Med Plants Res 1(2); 21-30.

Hasimuna P, Suwendara GIE. 2014. Analgesic Activity of Papaya (Carica papaya L.) Leaves Extract. Proc Chem 13, 147 - 149.

Islam A, Al-Mamun M, Parvin S, Sarker M, Zaman MK, Farhana P, Shahriar Z, Salah UM. 2015. Evaluation of antibacterial activities of latex of Caricaceae (Carica Papaya L.). Asian J Pharmaco Clin Res 8 (1):308-311.

Jackson AA. 2000. Adv Exp Med Bio. Plenum Press, New York.

Jyotsna KP, Yashab K, Priyanka P, Harison M. 2014. Antibacterial activity of seed and leaf extract of Carica Papaya var. Pusa dwarf Linn. J Pharm Bio Sci. 9(2): 29-37.

Kadiri O. 2015. Studies on the chemical composition, functional and antioxidant properties of Carica Papaya (Pawpaw) seed flour, protein concentrate and protein. M.sc thesis. Department of Food Science and Technology, Obafemi Awolowo University, Ile-Ife, Nigeria.

Kadiri O, Olawoye B. 2015. Underutilized Indigenous Vegetable (UIV) In Nigeria: A Rich Source of Nutrient and AntioxidantsA Review. Annals. Journal of Food Science \& Technology 16(2): 236-247.

Kadiri O, Olawoye B. 2016. Vernonia amygdalina: An Underutilized Vegetable with Nutraceutical Potentials - A Review. Turkish Journal of Agriculture - Food Science and Technology, 4(9): 763-768.

Kalou GB, Kimbonguila A, Nzikou M, Ganongo-Po FB, Moutoula FE. 2011. Extraction and characteristics of seed oil from Papaya (Carica papaya) in Congo-Brazzaville. Asian J Agric Sci 3(2): 132-137.

Kaibing Z, Hui W, Wenli M, Xiaona L, Ying L, Haofu D. 2011. Antioxidant Activity of Papaya Seed Extracts. Molecules 16: 6179-6192. 
Khaled NR, Gerda, F. 2013. Anticancer activity of Carica papaya extracts in vitro and phytochemical analysis. Gre J Pharm Pharmaco 1(1): 001-005.

Krishna K, Paridhavi, M. 2008. Review on nutritional, medicinal and pharmacological properties of papaya (Carica papaya Linn.). Nat Prod Radian, 7: 364-373.

Lim Y, Lim TT, Tee JJ. 2007. Antioxidant properties of several tropical fruits: A comparative study. Food Chem, 103 (3): 1003-1008.

Lisda H, Agung B, Eko, S. 2015. Aqueous extracts of seed and peel of Carica Papaya against Aedes Aegypti. J Med Bioeng 4(5): 417-421.

MacDonald-Wicks LK., Wood, L.G. and Garg, M.L. 2006. Methodology for the determination of biological antioxidant capacity in vitro: a review. Journal of the Science of Food and Agriculture, 86(13): 2046-2056.

Mahmood, T, Rahman MH, Stringam GR, Raney JP, Good AG. 2005. Molecular markers for seed colour in Brassica juncea. Genome, 48: 755-760.

Maisarah, AM, Asmah R, Fauziah O. 2014. Proximate analysis, antioxidant and antiproliferative activities of different parts of Carica Papaya. J Nutr Food Sci, 4: 1043-1048, http://dx.doi.org/10.4172/2155-9600.1000267.

Marshall EU, Chiwendu S, Ukpabi EO, Ezikpe, CA. 2015. Antimicrobial screening and phytochemical analysis of Carica papaya Leaf extracts. Stan Res J Microbiolo Sci 2(1): 001-004.

Mello VJ, Gomes MT, Lemos FO, Delfino JL, Andrade SP, Lopesand CE. 2008. The gastric ulcer protective and healing role of cysteine proteinases from Carica candamarcensis. Phytomed 15: 237-244.

Mohammed A, Abubakar SA, Sule MS. 2011.Hepatoprotective effect of aqueous leaf extract of Carica papaya Linn against CCL4-induced hepatic damage in rats. Int J Pharm Sci Rev Res 3(11)2: 13-16.

Morimoto C, Dang NH, Dang N. 2008. Therapeutic Co Ltd (YSTHNon-standard) Toudai Tlo Ltd (TOUDNon-standard) Morimoto C (MORI-Individual) Dang N H (DANG- Individual), Cancer prevention and treating composition for preventing, ameliorating, or treating solid cancers, e.g. lung, or blood cancers, e.g. lymphoma, comprises components extracted from brewing papaya. Patent number- WO2006004226-A1; EP1778262- A1; JP2008505887-W; US2008069907-A1, 2008.

Naresh CVM, Taranath V, Venkatamuni A, Vishnu R, Siva Y, Ravi U, Sai Gopal DVR. 2015. Therapeutic potential of Carica Papaya L. leaf extract in treatment of dengue patients. Int J Appli Bio Pharma Techno (6)3: 93-98.

Nguyen TT, Shaw PN, Parat MO, Hewavitharana AK.2013. Anticancer activity of Carica papaya: a review. Mol Nutr Food Res 57(1):153-64.

Nitsawang S, Hatti-Kaul R, Kanasawud P. 2006. Purification of papain from Carica papaya latex: Aqueous two-phase extraction versus two-step salt precipitation. Enzy Microbial Techno, 39(5): 1103-1107.

Otsuki N, Dang NH, Kumagai E, Kondo A, Iwata S, Morimoto C. 2010. Aqueous extract of Carica papaya leaves exhibits antitumor activity and immunomodulatory effects. $\mathbf{J}$ of Ethnopharmacolo, 127(3): 760-767.

Owoyele BV, Adebukola, O .M, Funmilayo AA, Soladoye AO. 2008. Anti-inflammatory activities of ethanolic extract of Carica papaya leaves. Inflammopharmacol, 16, 168-173.

Oyoyede OI. 2005. Chemical profile of unripe pulp of Carica papaya. Pak J Nutr 4(6): 379-381.

Pandit A, Sachdeva T, Bafna P. 2013. Ameliorative effect of leaves of Carica papaya in ethanol and antitubercular drug induced hepatotoxicity. British J Pharma Res 3(4): 648-661.

Paul CW, Ligha AE. 2015. Hydro-methanol extract of ripe Carica Papaya seed is not friendly with histology of albino wistar rats' liver. Asian J Med Sci 7(2): 17-21.

Parle M, Gurditta. 2011. Basketful benefits of Papaya. Nutr Food Sci 2 (7): 6-12.

Polonsky KS. 2012. The past 200 years in diabetes. J Med 367: 1332-1340.
Quan V, Vuong SH, Tiffany LK, Chuen CD, Goldsmith SM, Michael CB, Phoebe AP. Christopher, JS. 2015. Antioxidant and anticancer capacity of saponin-enriched Carica papaya leaf extracts. Int J Food Sci Tech 1-9, http://dx.doi.org/10.1111 /ijfs. 12618

Quan VV, Sathira H, Paul DR, Michael CB, Phoebe AP, Christopher JS. 2013. Effect of extraction conditions on total phenolic compounds and antioxidant activities of Carica papaya leaf aqueous extracts. J Herb Med 3: 104-111.

Runnie I, Salleh MN, Mohamed S, Head RJ, Abeywardena MY. Vaso-relaxation induced by common edible tropical plant extracts in isolated rat aorta and mesenteric vascular bed. $\mathbf{J}$ Ethnopharmaco 92: 311-316.

Samia F, El-Safy H, Rabab H. Salem, ME, Abd El-Ghany. 2012. Chemical and nutritional evaluation of different seed flours as novel sources of protein. World J Dairy Food Sci, 7 (1): 59-65.

Saran PL, Choudhary R. 2013. Drug bioavailability and traditional medicaments of commercially available papaya: A review. Afri J Agricul Res, 8 (25): 3216-3223.

Setiawan B, Suleiman A, Giraud DW, Driskell JA. 2001. Carotenoid content of selected Indonesian Fruits. J Food Comp Anal 14(2): 169-176.

Shadi S, Hamed M, Chin PT, Hasanah MG. 2013. Ultrasoundassisted extraction (UAE) and solvent extraction of papaya seed oil: Yield, fatty acid composition and triacylglycerol profile. Molecules, 18: 12474-12487.

Sheikh N, Neelam, Y, Tasleem, A. 2014. Effect of Carica papaya leaf formulation on Haematology and Serology of normal rat. Biologia 60 (1): 139-142.

Starley IF, Mohammed P, Schneider G, Bickler SW. 1999. The treatment of paediatric burns using topical papaya. Burns 25(7): 636-639.

Subramanian G, Brij B, Tewari, Rekha G. 2014. Antimicrobial properties of Carica papaya (Papaya) different Leaf Extract against E. coli, S. aureus and C. albicans. American J Pharmaco Pharmacotherapeu 1(1): 025-039.

Subenthiran S, Choon TC, Cheong KC, Thayan R, Teck MB , Muniandy PK, Afzan A, Abdullah NR, Zakiah I. 2013. Carica papaya leaves juice significantly accelerates the rate of increase in platelet count among patients with dengue fever and dengue haemorrhagic fever. Evid -Based Complem Alter Med, http://dx.doi.org/10.1155/2013/616737.

Suhas JV, Taslim T, Khatri VRR, Pragnesh, ND, Hitendra SJ. 2014. Biochemical constituents in leaf of Carica papaya - Ethnomedicinal plant of Kachchh region. Inter Letters Natu Sci 12: 16-20.

Syed HM, Kunte SP, Jadhav BA, Salve RV. 2012. Extraction and characterization of papaya seed Oil. Int J Appli Phy Biochem Res 2(1): 33-43.

Tarun V, Yash P. 2015. A review on medicinal properties of Carica papaya Linn. Asian Pac J Trop Dis 5(1): 1-6. doi: 10.1016/S2222-1808(14)60617-4

Umana UE, Timbuak JA, Danladi J, Samuel A, Joseph H, Anuka JA. 2014. Anti-inflammatory, antipyretic and antinociceptive activities of orally administered aqueous extract of Carica papaya seeds in animal models. Annals Exp Bio 2 (4): 21-27.

USDA National Nutrient Database for Standard Reference; http://ndb.nal.usda.gov.

Vijay K, Sriram S. 2010. Antioxidant activity of seed extracts of Annona squamosa and Carica papaya. Nutr Food Sci 40 (4): 403-408.

Wall MM. 2006. Ascorbic acid, vitamin A, and mineral composition of banana (Musa sp.) and papaya (Carica papaya) cultivars grown in Hawaii. J Food Compos Analy 19(5): 434-445.

Wong NK, Khor ES. 2014. Potential antioxidant and cytotoxic properties of secondary metabolite extracts from Carica papaya fruits and seeds. Int J Pharm Pharmaceut Sci 6(7).

Yusep I. 1997. The effect of fermentation and soaking times on pyrazines and acidity concentration of Thai Forastero cocoa beans. Bangkok, Thailand: Kasertsart University, MSc thesis.

Yusha'u M, Onuorah FC, Murtala Y. 2009. In-vitro sensitivity pattern of some urinary tract isolates to Carica papaya extracts. Bayero J Pure Appl Sci 2(2): 75 - 78. 